\title{
Economic Evaluation and Risk Analysis of the Bisha Volcanogenic Massive Sulphide Mining Project
}

\author{
Peter Arroja Eshun ${ }^{1 *}$ and Napoleon Baafi ${ }^{2}$ \\ ${ }^{1}$ Department of Mining Engineering, University of Mines and Technology, Ghana \\ ${ }^{2}$ Department of Mining Engineering, Perseus Mining Ghana Limited, Ghana \\ *Corresponding author: Peter ArrojaEshun, Department of Mining Engineering, University of Mines and Technology, PO Box 237,Tarkwa, Ghana
}

Submission: 悳June 11, 2018; Published: 眥July 10, 2018

\begin{abstract}
Bisha Mining Share Company (BMSC), Eritrea, is a subsidiary of Nevsun Resources of Canada. BMSC completed exploration work in the year 2005, which discovered Volcanogenic Massive Sulphide (VMS) deposit containing commercial quantities of gold, silver, copper and zinc at Bisha. An optimal open pit has been designed for the exploitation of the deposit using MineSight and Surpac software under the given geotechnical and economic parameters. The total tonnage from the optimised pit was 90161 903t at a stripping ratio of 3.4. A Life of Mine (LOM) schedule carried out in Minesched predicted a mine life of 10 years and defined the transitional periods for the exploitation of gold, silver, copper and zinc deposits. The objective of this paper is to determine the economic viability of the project with its associated risk under the Mining and Mineral Laws of Eritrea. With a capital structure of $100 \%$ equity, a discounted cash flow analysis was conducted which resulted in a Net Present Value (NPV) of US\$344 $553000 @ 10 \%$ discount rate and an Internal Rate of Return (IRR) of $29.9 \%$ which suggest the project to be economically viable. Sensitivity analysis conducted revealed that, the project will continue to be economically viable until the revenue decreases beyond $28.5 \%$. Risk analysis using Monte Carlo simulation indicated a risk of failure of $18 \%$. It is recommended that other financing sources such as long-term loans be exploited to further improve the economics and reduce the financial burden on the investors.
\end{abstract}

Keywords: Mineral project evaluation; Risk analysis; Cash flow analysis; Sensitivity analysis; Monte carlosimulation

\section{Introduction}

Mineral projects have a number of characteristics or features which make them somewhat unique from other investment opportunities. Gentry \& O’Neil [1] agree that the investment environment associated with the mining industry is unique when compared with the environment encountered by typical manufacturing industries and explain further that some of these characteristics include capital intensity, long preproduction periods, high risks and the fact that minerals are non-renewable resource.

Torries [2] defines mineral project evaluation as the process of identifying the economic feasibility of a mineral project that requires a capital investment and making the investment decision. De la Vergne [3] defines mineral economic evaluation as rational continuous process whereby final decisions on alternate choices, either of a different mining project or changes in parameters, such as production rates and methods are made. Tschabrun [4] is of the view that mineral economic evaluation is the method used to determine the economic viability of a mineral project and it is the primary measure of alternative investment opportunities. Eshun
\& Mireku [5] define mineral project evaluation as the economic analysis by which investment decisions are made with respect to mining projects.

From the given definitions, mineral economic evaluation can be defined as a pragmatic approach whereby a mineral investment is thoroughly examined using the project's economic parameters such as revenue, capital cost, operating cost, taxes and allowances in a discounted cash flow analysis to determine the viability of the project.

Risk analysis in mineral project evaluation allows a thoughtful consideration of both anticipated problems and unexpected occurrences. Consequently, any evaluation of a project's robustness must take into account its various risk areas and the potential for adverse interaction of those risks on the project. According to Rozman [6], the resources business like so many others is all about risk management. Seymour [7] argues that the key objective of a mining company is to maximize shareholder contribution within acceptable risks. Sayers et al. [8] define risk as a combination of the chance of a particular event, with the impact that the event would 
cause if it occurs. Hence risk analysis of a mineral project involves the investigation of the possible effect of changes in the economic parameters on the viability of the mineral project.

Bisha Mining Share Company (BMSC), Eritrea, is a subsidiary of Nevsun Resources of Canada. BMSC completed exploration work in the year 2005, which discovered Volcanogenic Massive Sulphide deposit containing commercial quantities of gold, silver, copper and zinc at Bisha. Net Smelter Returns values were modelled using a script developed in Surpac. The deposit was optimised and an open pit was designed using Mine Sight software under the given geotechnical and economic parameters with a marginal tonnage deviation of $3 \%$. A Life of Mine (LOM) schedule carried out in Minesched predicted a mine life of 10 years and defined the transitional periods for the exploitation of gold, copper and zinc deposits [9]. The objective of this paper is to determine the economic viability of the project with its associated risk under the Mining and Mineral Laws of Eritrea.

\section{Materials and Methods}

Data was obtained from BSMC and MS Excel software was used in the data analysis. Detailed method of estimation was employed in the capital cost, operating cost and revenue estimation. Discounted cash flow analysis was used to evaluate the economic viability of the project while sensitivity analysis was conducted to assess the level of independent changes in the economic parameters that the project could absorb and still be economically viable. Finally, risk analysis using Monte Carlo simulation was conducted to investigate the effect of simultaneous changes in the economic parameters on the viability of the project to estimate the probability of failure of the project.

\section{Capital cost estimation}

Basis of estimation: The following served as the basis in the estimation of the capital cost:

a. Capital cost estimates were based on price quotations from international and local suppliers and contractors.

b. Medium to long term capital expenditure comprised mainly of mining fleet replacement, process plant expansion and sustaining capital associated with tailings dam lifts and progressive community resettlement works.

c. Cost contingency allowance of $15 \%$ was applied to take care of uncertain elements within the project scope and to reduce the risk of cost overrun.

d. Table 1 presents the exchange rates used in converting the input pricing sourced in currencies other than US dollars for the capital cost estimates.

Table 1: Currency exchange rate.

\begin{tabular}{|c|c|c|}
\hline \multicolumn{2}{|c|}{ Currency } & Exchange Rate to USD \\
\hline Australia Dollar & AUD & 0.75 \\
\hline United States of America & USD & 1 \\
\hline
\end{tabular}

\begin{tabular}{|c|c|c|}
\hline Euro & Euro & 1.09 \\
\hline Canadian Dollar & CAD & 0.75 \\
\hline Swiss Franc & CHF & 1 \\
\hline British Pound & GBP & 1.52 \\
\hline South African Rand & ZAR & 0.07 \\
\hline Ghanaian Cedis & GHS & 0.26 \\
\hline Eritrean Nakfa & NKFA & 0.06 \\
\hline
\end{tabular}

\section{Capital cost estimates}

The bulk of the capital expenditure is incurred in the project's construction period and this is associated with the purchasing of the mine equipment, processing plant installation and infrastructural development. Table 2 presents the summary of the project's capital cost estimates. This has been grouped into three categories with the following codes:

Table 2: Capital cost summary.

\begin{tabular}{|c|c|c|}
\hline CCE & Description & Amount (US \$000's) \\
\hline CCE 1 & \multicolumn{2}{|c|}{ Direct Capital Cost } \\
\hline 1 & Mining & 44882 \\
\hline 2 & Processing & 167597 \\
\hline \multirow[t]{2}{*}{3} & Infrastructure and site works & 22657 \\
\hline & Subtotal & 235136 \\
\hline CCE 2 & \multicolumn{2}{|c|}{ Indirect Capital Cost } \\
\hline 1 & Acquisition \& exploration & 25000 \\
\hline 2 & Eia and environmental permit & 9500 \\
\hline 3 & Engineering and consultancy & 6400 \\
\hline 4 & Compensation and resettlement & 12820 \\
\hline 5 & General and adm mobile equipment & 3350 \\
\hline 6 & Commissioning & 80 \\
\hline 7 & Sustaining capital & 120000 \\
\hline \multirow[t]{2}{*}{8} & Mine development capital & 15000 \\
\hline & Subtotal & 192150 \\
\hline \multirow[t]{4}{*}{ CCE 3} & \multicolumn{2}{|l|}{ Allowance } \\
\hline & Contingency (15\%) & 64093 \\
\hline & Subtotal & 64093 \\
\hline & Grand Total & 491379 \\
\hline
\end{tabular}
a. CCE 1 Direct Capital Cost;
b. CCE 2 Indirect Capital Cost; and
c. CCE 3 Allowances

Each of the categories under the direct capital cost has been expanded into specific costs under appropriate headings. These are presented in Table 3-5. 
Table 3: Detailed mining capital cost.

\begin{tabular}{|c|c|c|c|c|}
\hline MCC & Description & Qty & Unit Price (\$’000) & Amt (\$'000) \\
\hline MCC 1 & \multicolumn{4}{|c|}{ Mobile equipment } \\
\hline 1.1 & ROC L8 drill & 3 & 795 & 2385 \\
\hline 1.2 & Pantera 1500 drill & 1 & 450 & 450 \\
\hline 1.3 & Terex RH40 excavator & 3 & 1580 & 4740 \\
\hline 1.4 & CAT 990H loader & 1 & 1345 & 1345 \\
\hline 1.5 & CAT $966 \mathrm{H}$ loader & 1 & 1821 & 1821 \\
\hline 1.6 & 20,000 Litre water truck & 1 & 45 & 45 \\
\hline 1.7 & Cat d10t dozer & 2 & 1740 & 3480 \\
\hline 1.8 & Cat $\mathrm{d} 8$ dozer & 1 & 1040 & 1040 \\
\hline 1.9 & Cat 16 grader & 3 & 600 & 1800 \\
\hline 1.1 & CAT 775 truck & 12 & 985 & 11820 \\
\hline 1.11 & CAT 775 Water truck & 1 & 579 & 579 \\
\hline 1.12 & $2 \mathrm{~m}^{3}$ Backhoe & 1 & 90 & 90 \\
\hline 1.13 & Cs 683 compactor & 1 & 185 & 185 \\
\hline 1.14 & Explosive truck & 1 & 140 & 140 \\
\hline 1.15 & Cat 365 CL $2.4 \mathrm{~m}^{3}$ & 1 & 530 & 530 \\
\hline 1.16 & Tyre handler, $966^{\mathrm{TH}}$ & 1 & 475 & 475 \\
\hline 1.17 & Low loader & 1 & 1500 & 1500 \\
\hline 1.18 & Mine utility vehicle & 20 & 65 & 1300 \\
\hline \multirow[t]{2}{*}{1.19} & 33-Seater mini bus & 2 & 65 & 130 \\
\hline & \multicolumn{3}{|c|}{ Subtotal } & 33855 \\
\hline MCC 2 & \multicolumn{4}{|c|}{ Miscellaneous capital items } \\
\hline 2.1 & Light plant & 5 & 80 & 400 \\
\hline 2.2 & Stadium lights & 5 & 100 & 500 \\
\hline 2.3 & Mining software & 1 & 612 & 612 \\
\hline \multirow[t]{2}{*}{2.4} & Survey equipment & 1 & 540 & 540 \\
\hline & \multicolumn{3}{|c|}{ Subtotal } & 2052 \\
\hline MCC 3 & Dewatering equipment and installation & & & \\
\hline 3.1 & Pit dewatering ring bores & 6 & 400 & 2400 \\
\hline 3.2 & In-pit pumps & 5 & 100 & 500 \\
\hline \multirow[t]{2}{*}{3.3} & Standpipes/transfer & 2 & 200 & 400 \\
\hline & \multicolumn{3}{|c|}{ Subtotal } & 3300 \\
\hline $\operatorname{MCC} 4$ & Mining facilities & & & \\
\hline 4.1 & Mining adm building & & & 950 \\
\hline 4.2 & Mine workshop & & & 1600 \\
\hline 4.3 & Wash down facility & & & 471 \\
\hline 4.4 & Mine rescue & & & 104 \\
\hline 4.5 & Fuel storage facility & & & 1000 \\
\hline \multirow[t]{2}{*}{4.6} & Mine services facility & & & 400 \\
\hline & \multicolumn{3}{|c|}{ Subtotal } & 4525 \\
\hline MCC 5 & \multicolumn{3}{|c|}{ Explosives infrastructure } & \\
\hline 5.1 & Explosives magazine and ANFO mixing plant & & & 1150 \\
\hline
\end{tabular}




\begin{tabular}{|c|c|c|}
\hline & Subtotal & 1150 \\
\hline & Grand total & 44882 \\
\hline
\end{tabular}

Table 4: Detailed processing capital cost.

\begin{tabular}{|c|c|c|}
\hline PCC & Description & Amount (\$'000) \\
\hline PCC 1 & \multicolumn{2}{|l|}{ Processing plant } \\
\hline \multirow[t]{2}{*}{1.1} & $\begin{array}{l}\text { Complete plant includes the following plus delivery: Sag and Ball grinding mill, Cyanide leach/Carbon-in-leach } \\
\text { (CIL) circuit, cyanide destruction circuit, refinery to be produced dore bullion, tailings thickener, tailings discharge } \\
\text { system and necessary regent, water and air systems }\end{array}$ & 125000 \\
\hline & Subtotal & 125000 \\
\hline PCC 2 & \multicolumn{2}{|l|}{ Additional equipment for supergene } \\
\hline \multirow[t]{2}{*}{2.1} & $\begin{array}{l}\text { Flotation cells, for copper roughing and cleaning duties, regrind mills for rougher concentrate, copper concentrate } \\
\text { thickener, and pressure filters, copper concentrate load out building, copper floatation reagent systems, floatation } \\
\text { air blowers, and pressure filter air compressors }\end{array}$ & 1224 \\
\hline & Subtotal & 1224 \\
\hline PCC 3 & \multicolumn{2}{|l|}{ Additional equipment for zinc } \\
\hline \multirow[t]{2}{*}{3.1} & $\begin{array}{c}\text { Flotation cells, for zinc roughing and cleaning duties, regrind mills for rougher concentrate, zinc concentrate } \\
\text { thickener, and pressure filters, zinc concentrate load out building, copper floatation reagent systems, floatation air } \\
\text { blowers, and pressure filter air compressors }\end{array}$ & 1224 \\
\hline & Subtotal & 1224 \\
\hline PCC 4 & \multicolumn{2}{|l|}{ Plant infrastructure } \\
\hline 4.1 & Plant buildings & 843 \\
\hline 4.2 & Laboratory complex & 555 \\
\hline \multirow[t]{2}{*}{4.3} & Tailings dam & 4509 \\
\hline & Subtotal & 5907 \\
\hline PCC 5 & Reagents \& plant services & \\
\hline 5.1 & Reagents & 8550 \\
\hline 5.2 & Water services & 1646 \\
\hline 5.3 & Process control system & 2035 \\
\hline 5.4 & Compressed air services & 1495 \\
\hline 5.5 & Electrical services & 3244 \\
\hline 5.6 & Fuels & 325 \\
\hline 5.7 & Initial spares and 1-month consumables & 1260 \\
\hline \multirow[t]{2}{*}{5.8} & Instrumentation and automation & 1800 \\
\hline & Subtotal & 20355 \\
\hline PCC 6 & \multicolumn{2}{|l|}{ Port logistics and rotainer } \\
\hline 6.1 & Port logistics & 593 \\
\hline 6.2 & Rotainer based transport & 5509 \\
\hline \multirow[t]{2}{*}{6.3} & Port storage facility & 2025 \\
\hline & Subtotal & 8127 \\
\hline PCC 7 & \multicolumn{2}{|l|}{ Process plant mobile fleet } \\
\hline 7.1 & Crane-200T (1) & 1879 \\
\hline 7.2 & Boom-20T (1) & 90 \\
\hline 7.3 & Hdpe welding unit (1) & 114 \\
\hline
\end{tabular}




\begin{tabular}{|c|c|c|}
\hline 7.4 & Mobile welding machines (1) & 25 \\
\hline 7.5 & Cat 990h loader (2) & 2690 \\
\hline 7.6 & Bobcats (1) & 78 \\
\hline 7.7 & Forklifts (2) & 70 \\
\hline 7.8 & Cs 683 compactor (1) & 250 \\
\hline 7.9 & $4 \times 4$ Toyota Pick-up (4) & 330 \\
\hline 7.1 & Dual cab4wd land cruiser (6) & 130 \\
\hline 7.11 & 33-seater buses (2) & $\mathbf{5 7 6 0}$ \\
\hline & Subtotal & $\mathbf{1 6 7 5 9 7}$ \\
\hline
\end{tabular}

Table 5: Detailed infrastructural capital cost.

\begin{tabular}{|c|c|c|}
\hline \multirow{2}{*}{ ICC } & Description & Amount \\
\cline { 3 - 3 } & Infrastructure and site works \\
\hline ICC 1 & Site development & 2593 \\
\hline 1.1 & Environmental unit \\
\hline 1.2 & Utilities \& services & 618 \\
\hline 1.3 & Power generation and reticulation & 513 \\
\hline 1.4 & Adm and management offices & 1874 \\
\hline 1.5 & Warehouse and spares store & 1250 \\
\hline 1.6 & Maintenance workshop & 1456 \\
\hline 1.7 & Construction camp & 2250 \\
\hline 1.8 & Permanent camp complex & 8750 \\
\hline 1.9 & Fire service & 240 \\
\hline 1.1 & It hardware/software & 1255 \\
\hline 1.11 & Communication services & 903 \\
\hline 1.12 & Site security & 800 \\
\hline 1.13 & Total & $\mathbf{2 2 ~ 6 5 7}$ \\
\hline &
\end{tabular}

\section{Operating cost estimation}

Basis of estimation: The cost estimate for the mining operation is based on owner mining. Equipment operation and maintenance will be carried out by the parent company. The operating cost estimates for mining and processing were assembled from quotations given to 'peer' companies within the African Region and from current NI 43-101 technical reports [10]. Additional prices were sourced from suppliers of ancillary equipment, explosives and blasting services. All costs are presented on yearly basis in the year in which they are incurred and they are based on working regime of 2shifts/day, $9.8 \mathrm{hr} / \mathrm{shift}$ for 360 days/year. The estimated average equipment operating hours is 4862 .

Most of the skilled labour will be expatriates for the first five years of the project life and all the unskilled labour will be Eritreans. All cost estimates will be based on the base mining schedule. The project operating cost estimate includes all recurring costs for payroll, service camp operations, contractors, maintenance parts and supplies, reagents, consumables, supplies, freight, personnel transportation, etc. to operate all facilities expensed in the tax year in which they occur. These estimates have been developed from first principles and grouped into categories. Each category has been expanded into specific costs under appropriate headings to provide detail cost estimates.

The categories include:
A. OCE 1 Mining;
B. OCE 2 Processing and
C. OCE 3 General and Administration.

Table 6: Project total operating cost summary.

\begin{tabular}{|c|c|c|}
\hline OCE & Description & Amount (\$'000) \\
\hline OCE 1 & Mining operating expenditure \\
\hline 1.1 & Blasting & 14095 \\
\hline 1.2 & Excavator operation & 44922 \\
\hline 1.3 & Dump truck operating & 13456 \\
\hline 1.4 & Mine auxiliary equipment & 30448 \\
\hline 1.5 & Mine labour & 51598 \\
\hline 1.6 & Miscellaneous & 114685 \\
\hline 1.7 & Subtotal & 26921 \\
\hline & Processing plant operating cost \\
\hline
\end{tabular}




\begin{tabular}{|c|c|c|}
\hline 1.1 & Consumables & 211497 \\
\hline 1.2 & Mobile equipment & 6180 \\
\hline 1.3 & Electric power & 114702 \\
\hline 1.4 & Off site administration & 15921 \\
\hline 1.5 & Process \& maintenance labour & 105260 \\
\hline \multirow[t]{2}{*}{1.6} & Miscellaneous & 45356 \\
\hline & Subtotal & 498916 \\
\hline OCE 3 & \multicolumn{2}{|c|}{ General and administrative } \\
\hline 1.1 & Head office charges & 1440 \\
\hline 1.2 & Office administration - site & 2210 \\
\hline 1.3 & Insurances & 13140 \\
\hline 1.4 & Financial & 1410 \\
\hline 1.5 & Fees and taxes & 6750 \\
\hline 1.6 & Consultants & 3340 \\
\hline 1.7 & Personnel affairs & 7690 \\
\hline 1.8 & Contracts & 26700 \\
\hline 1.9 & General maintenance & 14730 \\
\hline 1.1 & Mobile equipment & 3840 \\
\hline 1.11 & Admin labour & 57432 \\
\hline 1.12 & Miscellaneous & 13869 \\
\hline & Subtotal & 152551 \\
\hline & Grand total & 947592 \\
\hline
\end{tabular}

Table 7: Project yearly operating cost summary.

\begin{tabular}{|c|c|c|c|c|c|c|c|c|c|c|c|}
\hline Cost Centre & TOTAL & Y1 & Y2 & Y3 & Y4 & Y5 & Y6 & Y7 & Y8 & Y9 & Y10 \\
\hline Mining operating cost & $\begin{array}{l}296 \\
125\end{array}$ & 38229 & 38187 & 33833 & 32451 & 30349 & 31238 & 30745 & 28051 & 20173 & 12869 \\
\hline Processing operating cost & $\begin{array}{l}498 \\
916\end{array}$ & 54416 & 61425 & 49897 & 52182 & 47203 & 46646 & 50714 & 50490 & 50830 & 35113 \\
\hline General and Adm Cost & $\begin{array}{l}152 \\
551\end{array}$ & 15564 & 15564 & 15564 & 15564 & 15564 & 15564 & 15564 & 15564 & 15564 & 12475 \\
\hline Total (US \$000) & $\begin{array}{l}947 \\
592\end{array}$ & 108207 & 115174 & 99293 & $\begin{array}{l}100 \\
194\end{array}$ & 93114 & 93446 & 97022 & 94103 & 86566 & 60457 \\
\hline
\end{tabular}

The estimated total operating cost for mining, processing and G\&A are US \$296M, US \$498M, 152M respectively. Table 6 presents the summary of the project total operating cost whilst Table 7 gives the yearly operating cost summary.

\section{Mining operating cost details}

The mining operating cost estimation includes:

A. All requirements for drilling, blasting, loading, hauling and dumping of ore to the crusher or ROM pad and waste to either the waste dump or dump for tailings dam wall construction purposes;

B. All auxiliary operations such as haul road construction and drainage maintenance;
C. All mining technical services including survey and geotechnical activities;

D. The open pit production geology, resource modelling and grade control functions;

E. All Mining department management, supervision, operating and maintenance manpower requirements up to and including the Mining Manager;

F. All equipment operating costs and consumables such as repairs, tyres, tracks, lubricants, fuel, wear parts, explosives and major overhauls are based on vendor supplied information, and industrial experience. The summary is presented in Table 8. 
Table 8: Mining operating cost summary.

\begin{tabular}{|c|c|c|c|c|c|c|c|c|c|c|c|}
\hline Cost Centre & LOM & Y1 & Y2 & Y3 & Y4 & Y5 & Y6 & Y7 & Y8 & Y9 & Y10 \\
\hline $\begin{array}{c}\text { Total material } \\
\text { (t'000) }\end{array}$ & 92976 & 13885 & 14651 & 10929 & 10457 & 9568 & 9112 & 9047 & 8319 & 4782 & 2226 \\
\hline Drilling & 14095 & 2807 & 2829 & 1574 & 1275 & 1025 & 1178 & 1188 & 1246 & 708 & 265 \\
\hline Blasting & 44922 & 8092 & 8130 & 5468 & 4564 & 3481 & 4211 & 4245 & 3889 & 2065 & 777 \\
\hline Excavator & 13456 & 1539 & 1539 & 1539 & 1539 & 1448 & 1448 & 1448 & 1267 & 1086 & 603 \\
\hline Dump Truck & 30448 & 4029 & 3930 & 3889 & 3836 & 3402 & 3709 & 3217 & 2588 & 1275 & 573 \\
\hline Auxiliary & 51598 & 5479 & 5479 & 5479 & 5479 & 5426 & 5275 & 5275 & 5275 & 4572 & 3859 \\
\hline Labour & 114685 & 12808 & 12808 & 12808 & 12808 & 12808 & 12577 & 12577 & 11236 & 8633 & 5622 \\
\hline Miscellaneous & 26921 & 3475 & 3472 & 3076 & 2950 & 2759 & 2840 & 2795 & 2550 & 1834 & 1170 \\
\hline Total (US\$ 000) & 296125 & 38229 & 38187 & 33833 & 32451 & 30349 & 31238 & 30745 & 28051 & 20173 & 12869 \\
\hline$(\mathrm{US} \$ / \mathrm{t})$ & 3.28 & 2.75 & 2.61 & 3.1 & 3.1 & 3.17 & 3.43 & 3.4 & 3.37 & 4.22 & 5.78 \\
\hline
\end{tabular}

\section{Process plant operating cost}

The processing operating cost consists of reagents and consumables, plant maintenance parts, fuel and lubricants, general administration, offsite administration expenses, electric power plant services and labour. The summary of the processing cost is presented in Table 9.

Table 9: Summary of process plant operating cost.

\begin{tabular}{|c|c|c|c|c|c|c|c|c|c|c|c|}
\hline Cost Centre & LOM & Y1 & Y2 & Y3 & Y4 & Y5 & Y6 & Y7 & Y8 & Y9 & Y10 \\
\hline Total material (t'000) & 21228 & 2000 & 2348 & 2133 & 2330 & 2156 & 2101 & 2056 & 2038 & 2066 & 2000 \\
\hline Reagent \& Cons. & 211497 & 25000 & 31111 & 20793 & 22721 & 18326 & 17860 & 21593 & 21402 & 21691 & 11000 \\
\hline Mobile Equip. & 6180 & 618 & 618 & 618 & 618 & 618 & 618 & 618 & 618 & 618 & 618 \\
\hline Electric Power & 114702 & 11825 & 11825 & 11825 & 11825 & 11825 & 11825 & 11825 & 11825 & 11825 & 8277 \\
\hline Port Utilities & 15921 & 1500 & 1761 & 1599 & 1748 & 1617 & 1576 & 1542 & 1529 & 1549 & 1500 \\
\hline Labour & 105260 & 10526 & 10526 & 10526 & 10526 & 10526 & 10526 & 10526 & 10526 & 10526 & 10526 \\
\hline Miscellaneous & 45356 & 4947 & 5584 & 4536 & 4744 & 4291 & 4241 & 4610 & 4590 & 4621 & 3192 \\
\hline Total (US\$ 000) & $\begin{array}{l}498 \\
916\end{array}$ & 54416 & 61425 & 49897 & 52182 & 47203 & 46646 & 50714 & 50490 & 50830 & 35113 \\
\hline$(U S \$ / t)$ & 23.77 & 27.21 & 26.16 & 23.4 & 22.39 & 21.89 & 22.2 & 24.66 & 24.77 & 24.61 & 17.56 \\
\hline
\end{tabular}

\section{General and administration (G\&A) cost}

General and administration cost were assembled from local and international contractors, agents, suppliers, and mining companies in operation. Major cost centres include: general maintenance, financial, insurance, contracts, and administration labour costs. It also includes fees and taxes, travel and accommodation, consultant and operating vehicle costs for the day to day running of the project. Table 10 shows the summary of the G\&A cost.

Table 10: General and administration cost summary.

\begin{tabular}{|c|c|c|c|c|c|c|c|c|c|c|c|}
\hline Cost Centre & LOM & Y1 & Y2 & Y3 & Y4 & Y5 & Y6 & Y7 & Y8 & Y9 & Y10 \\
\hline Total material (t'000) & $\mathbf{2 1 2 2 8}$ & $\mathbf{2 ~ 0 0 0}$ & $\mathbf{2 3 4 8}$ & $\mathbf{2 1 3 3}$ & $\mathbf{2 3 3 0}$ & $\mathbf{2 ~ 1 5 6}$ & $\mathbf{2 ~ 1 0 1}$ & $\mathbf{2 ~ 0 5 6}$ & $\mathbf{2 ~ 0 3 8}$ & $\mathbf{2 ~ 0 6 6}$ & $\mathbf{2 ~ 0 0 0}$ \\
\hline Head office charges & 1440 & 144 & 144 & 144 & 144 & 144 & 144 & 144 & 144 & 144 & 144 \\
\hline Office adm-site & 2210 & 221 & 221 & 221 & 221 & 221 & 221 & 221 & 221 & 221 & 221 \\
\hline Insurances & 13140 & 1314 & 1314 & 1314 & 1314 & 1314 & 1314 & 1314 & 1314 & 1314 & 1314 \\
\hline Financial & 1410 & 141 & 141 & 141 & 141 & 141 & 141 & 141 & 141 & 141 & 141 \\
\hline Fees and taxes & 6750 & 675 & 675 & 675 & 675 & 675 & 675 & 675 & 675 & 675 & 675 \\
\hline Consultants & 3340 & 334 & 334 & 334 & 334 & 334 & 334 & 334 & 334 & 334 & 334 \\
\hline Personnel Affairs & 7690 & 769 & 769 & 769 & 769 & 769 & 769 & 769 & 769 & 769 & 769 \\
\hline Contracts & 26700 & 2670 & 2670 & 2670 & 2670 & 2670 & 2670 & 2670 & 2670 & 2670 & 2670 \\
\hline General Maintenance & 14730 & 1473 & 1473 & 1473 & 1473 & 1473 & 1473 & 1473 & 1473 & 1473 & 1473 \\
\hline
\end{tabular}




\begin{tabular}{|c|c|c|c|c|c|c|c|c|c|c|c|}
\hline Mobile Equipment & 3840 & 384 & 384 & 384 & 384 & 384 & 384 & 384 & 384 & 384 & 384 \\
\hline Admin Labour & 57432 & 6024 & 6024 & 6024 & 6024 & 6024 & 6024 & 6024 & 6024 & 6024 & 3216 \\
\hline Miscellaneous (10\%) & 13869 & 1415 & 1415 & 1415 & 1415 & 1415 & 1415 & 1415 & 1415 & 1415 & 1134 \\
\hline (US \$000) & 152551 & 15564 & 15564 & 15564 & 15564 & 15564 & 15564 & 15564 & 15564 & 15564 & 12475 \\
\hline (US\$/t) & 7.22 & 7.78 & 6.63 & 7.30 & 6.68 & 7.22 & 7.41 & 7.57 & 7.64 & 7.53 & 6.24 \\
\hline
\end{tabular}

\section{Revenue estimation}

One of the advantages of NSR is quick revenue estimation. The total revenue was estimated using NSR values and the annual

Table 11: Revenue estimation.

\begin{tabular}{|c|c|c|c|c|c|c|c|c|c|c|c|}
\hline Cost Centre & LOM & Y2 & Y3 & Y4 & $\mathbf{Y}$ & Y6 & Y7 & Y\& & & & Y10 \\
\hline Total Ore (t) & & 2000 & 2348 & 2133 & 2330 & 2156 & 2101 & 2056 & 2038 & 2066 & $\begin{array}{c}2 \\
000\end{array}$ \\
\hline $\mathrm{Au}\left(\mathrm{t}^{\prime} 000\right)$ & 3958 & 2000 & 1945 & 12 & 0.238 & & & & & & \\
\hline NSR & 196 & 162 & 231 & 176 & 59 & & & & & & \\
\hline Rev (US\$000) & 774220 & 323486 & 448527 & 2193 & 14 & & & & & & \\
\hline Sup-Cu $\left(t^{\prime} 000\right)$ & 5540 & & 291 & 2006 & 1990 & 1173 & 39 & 32 & 9 & & \\
\hline NSR & 213 & & 265 & 253 & 201 & 154 & 173 & 241 & 228 & & \\
\hline Rev (US\$000) & 1180859 & & 77109 & 506945 & $\begin{array}{l}399 \\
739 \\
\end{array}$ & $\begin{array}{l}180 \\
386\end{array}$ & 6811 & 7796 & 2073 & & \\
\hline $\operatorname{Pr}-\mathrm{Cu}\left(\mathrm{t}^{\prime} \mathbf{0 0 0}\right)$ & 6009 & & 111 & 91 & 259 & 405 & 1235 & 846 & 837 & 852 & $\begin{array}{c}1 \\
371\end{array}$ \\
\hline NSR & 58 & & 36 & 36 & 36 & 76 & 39 & 46 & 61 & 67 & 76 \\
\hline Rev (US\$000) & 346447 & & 3956 & 3243 & 9204 & 30822 & 47987 & $\begin{array}{c}38 \\
587\end{array}$ & 51289 & 57020 & $\begin{array}{l}104 \\
339\end{array}$ \\
\hline $\operatorname{Pr}-Z n\left(t^{\prime} 000\right)$ & 5721 & & & 23 & 81 & 578 & 826 & 1178 & 1193 & 1213 & 629 \\
\hline NSR & 55 & & & 36 & 36 & 36 & 43 & 56 & 62 & 62 & 62 \\
\hline Rev (US\$000) & 314275 & & & 826 & 2865 & 20588 & 35505 & $\begin{array}{c}66 \\
348\end{array}$ & 74415 & 74719 & $\begin{array}{c}39 \\
009\end{array}$ \\
\hline $\begin{array}{l}\text { Total Rev } \\
\text { (US\$ 000) }\end{array}$ & 2615801 & $\begin{array}{l}323 \\
486\end{array}$ & 529592 & 513207 & $\begin{array}{l}411 \\
822\end{array}$ & $\begin{array}{l}231 \\
796\end{array}$ & 90303 & $\begin{array}{l}112 \\
731\end{array}$ & 127777 & $\begin{array}{l}131 \\
739\end{array}$ & $\begin{array}{l}143 \\
348\end{array}$ \\
\hline
\end{tabular}

\section{Discounted cash flow analysis}

The discounted cash flow method was used to evaluate the economic viability of the mineral project because of its simplicity and wider acceptability. The following general parameters were used in the cash flow analysis considering the Mining and Mineral laws of Eritrea:

a. A 5\% royalty is payable, for precious metals, on the net smelter return;

b. A 3.5\% royalty is payable, for base metals, on the net smelter return;

c. An income tax rate of $38 \%$ was applied over the life-ofmine;

d. Capital Allowance (Straight Line Depreciation) for 4 years and ore tonnages. The total revenue is US \$2 615801000 . Table 11 presents the summary of the revenue estimation on annual basis for the LOM. 
project, are all only estimates. Now, every estimated value has some degree of error associated with it and therefore may not be the real value. Again, by the time a mining project is being commissioned, all estimated values of the economic parameters may have changed.

Sorentino \& Barnett [11] therefore, describe sensitivity analysis as the process of examining the impact of errors. The approach is to vary one of the economic parameters while keeping the others constant and calculating the NPV and IRR consequent to the changes. A graph of the NPV and IRR against the changes in the economic parameter will give the effect of the change in the parameter on the viability of the project. The main purpose is to identify those variables that have the most significant impact on the viability of the project.

However, sensitivity analysis by itself cannot and will not measure the uncertainties of an investment alternative; it provides no estimate of the probability that the contemplated change will really occur. Furthermore, it is mostly desirable to know the cumulative effect on viability of simultaneous variations in all or several of the variables. This combined effect is not shown in sensitivity analysis but rather in risk analysis using the Monte Carlo simulation method (among others).

\section{Risk analysis by monte carlo simulation method}

Barish \& Kaplan [12] assert that simulation is the use of a model which takes account of those essentials of reality which are significant to the decision-making objective. Indeed, Sturgal \&
Harrison [13] point out that a simulation model should accurately and quickly represent a real-life situation. Shamblin \& Stevens [14] affirm that simulation is a powerful tool that is particularly useful in analyzing systems which are too complex for mathematical analysis.

It is the process of assessing the simultaneous effect that the input variables have on the viability of the project. Since there are many risk elements to consider and because the interaction requires complex calculations, the only practical method available is to perform the cash flow calculations on a computer. The approach is to quantify the variability of the input variables, sample the distributions in a random manner, calculate the cash flows for each set of input data, repeat the procedure many times, and display the result as a probability distribution of expected Internal Rate of Return (IRR) and Net Present Values (NPV).

\section{Results and Discussion}

\section{Project discounted cash flow analysis}

Table 12 shows the details of the cash flow analysis reported to the nearest 1000. The Net Present Value (NPV) @10\% discount rate for the project is US \$344553000 and Internal Rate of Return (IRR) of the project is estimated to be $29.9 \%$. As the NPV of US $\$ 344553000$ is greater than zero and IRR of $29.9 \%$ is greater than the discount rate of $10 \%$, the Bisha project is evaluated to be economically viable.

Table 12: Cash flow analysis of the bisha VMS project.

\begin{tabular}{|c|c|c|c|c|c|c|c|c|c|c|c|}
\hline $\begin{array}{c}\text { Equity Capital }=100 \% \\
\text { Loan Capital }=0 \% \\
\text { Total Capital Investment } \\
\text { Working Capital } \\
\text { Total Operating Cost (LOM) }\end{array}$ & \multicolumn{2}{|c|}{$\begin{array}{l}=\text { US } \$ 491380 \\
\quad=\text { US } \$ 0 \\
=\text { US } \$ 491380 \\
=\text { US } \$ 108207 \\
=\text { US } \$ 947592\end{array}$} & \multicolumn{2}{|c|}{$\begin{array}{c}\text { Royalty Precious } \\
\text { Metal } \\
\text { Royalty Base Metal } \\
\text { Project Life } \\
\text { Discount Rate } \\
\text { Percentage equity }\end{array}$} & \multicolumn{2}{|c|}{$\begin{array}{l}=5 \% \\
=3.5 \% \\
=10 \mathrm{yrs} \\
=10 \% \\
=100 \%\end{array}$} & \multicolumn{5}{|c|}{ (Cash Flow Computed in \$’000) } \\
\hline & 0 & 1 & 2 & 3 & 4 & 5 & 6 & 7 & 8 & 9 & 10 \\
\hline Gross Rev (Total NSR) & & 323486 & 529592 & 513207 & 411822 & 231796 & $\begin{array}{c}90 \\
303\end{array}$ & $\begin{array}{l}112 \\
731\end{array}$ & $\begin{array}{l}127 \\
777\end{array}$ & $\begin{array}{l}131 \\
739\end{array}$ & 143348 \\
\hline \multicolumn{12}{|c|}{ Less: } \\
\hline Royalty (Precious Metal) & & 16174 & 22426 & 110 & 1 & & & & & & \\
\hline Royalty (Base Metal) & & & 2837 & 17885 & 14413 & 8113 & $\begin{array}{c}3 \\
161\end{array}$ & 3946 & $\begin{array}{c}4 \\
472\end{array}$ & $\begin{array}{c}4 \\
611\end{array}$ & 5017 \\
\hline Operating Cost & & 108209 & 115176 & 99294 & 100197 & 93116 & $\begin{array}{c}93 \\
448\end{array}$ & $\begin{array}{c}97 \\
023\end{array}$ & $\begin{array}{c}94 \\
105\end{array}$ & $\begin{array}{c}86 \\
567\end{array}$ & 60457 \\
\hline Net Revenue (Rn) & & 199105 & 389155 & 399919 & 297214 & 130569 & $\begin{array}{c}-6 \\
304\end{array}$ & $\begin{array}{c}11 \\
763\end{array}$ & $\begin{array}{c}29 \\
202\end{array}$ & $\begin{array}{c}40 \\
562\end{array}$ & 77874 \\
\hline \multicolumn{12}{|c|}{ Less: } \\
\hline Reinvestment Allowance & & 16174 & 26480 & 25660 & 20591 & 11590 & $\begin{array}{c}4 \\
515\end{array}$ & 5637 & $\begin{array}{c}6 \\
389\end{array}$ & $\begin{array}{c}6 \\
587\end{array}$ & 7167 \\
\hline
\end{tabular}




\begin{tabular}{|c|c|c|c|c|c|c|c|c|c|c|c|}
\hline Depreciation & & 122845 & 122845 & 122845 & 122845 & & & & & & \\
\hline \multicolumn{12}{|l|}{ Interest } \\
\hline Loss Carry Forward & & & & & & & & 4515 & & & \\
\hline Taxable Income (Ti) & & 60084 & 239828 & 247413 & 153775 & 118977 & $\begin{array}{l}-10 \\
821\end{array}$ & 1610 & $\begin{array}{c}22 \\
811\end{array}$ & $\begin{array}{c}33 \\
974\end{array}$ & 70707 \\
\hline Tax, $\mathrm{T}=(38 \%$ Of $\mathrm{Ti})$ & & 22832 & 91135 & 94017 & 58434 & 45211 & & 612 & $\begin{array}{c}8 \\
668\end{array}$ & $\begin{array}{c}12 \\
910\end{array}$ & 26869 \\
\hline Net Income & & 37252 & 148694 & 153396 & 95340 & 73766 & $\begin{array}{l}-10 \\
821\end{array}$ & 998 & $\begin{array}{c}14 \\
143\end{array}$ & $\begin{array}{c}21 \\
064\end{array}$ & 43838 \\
\hline Reinvestment Allowance & & 16174 & 26480 & 25660 & 20591 & 11590 & $\begin{array}{c}4 \\
515\end{array}$ & 5637 & $\begin{array}{c}6 \\
389\end{array}$ & $\begin{array}{c}6 \\
587\end{array}$ & 7167 \\
\hline Depreciation & & 122845 & 122845 & 122845 & 122845 & & & & & & \\
\hline Loss Carry Forward & & & & & & & & 4515 & & & \\
\hline Working Capital (Last Yr Only) & & & & & & & & & & & 108207 \\
\hline \multicolumn{12}{|c|}{ Less } \\
\hline Working Capital (First Yr Only) & & 108207 & & & & & & & & & \\
\hline Equity Capital & 491380 & & & & & & & & & & \\
\hline \multicolumn{12}{|l|}{ Loan Repayment } \\
\hline Cash Flow (Cf) & $\begin{array}{c}-491 \\
380\end{array}$ & 68065 & 298018 & 301901 & 238777 & 85356 & $\begin{array}{c}-6 \\
306\end{array}$ & $\begin{array}{c}11 \\
150\end{array}$ & $\begin{array}{c}20 \\
532\end{array}$ & $\begin{array}{c}27 \\
651\end{array}$ & 159212 \\
\hline Npv@ 10\%= & 344553 & & & & & & & & & & \\
\hline Irr $=$ & $29.9 \%$ & & & & & & & & & & \\
\hline
\end{tabular}

\section{Project sensitivity analysis}

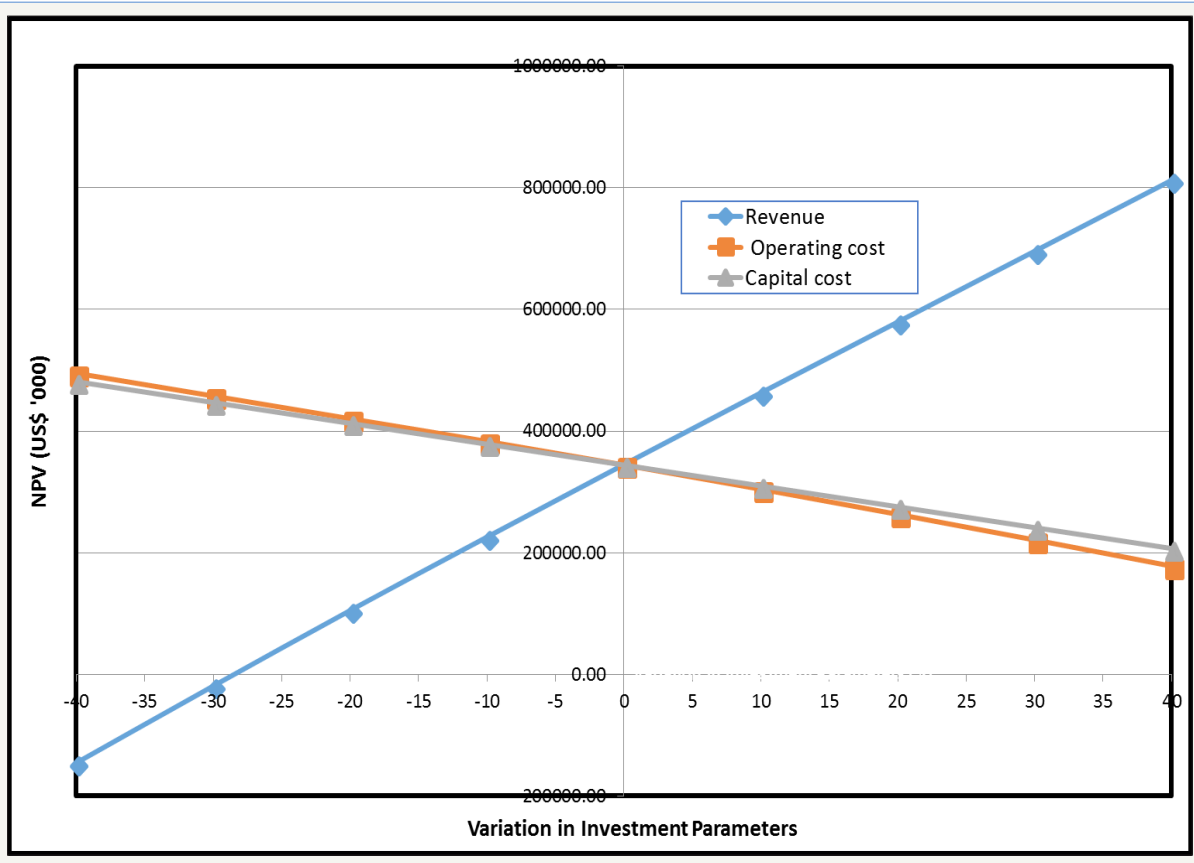

Figure 1: Variation of economic parameters with NPV. 


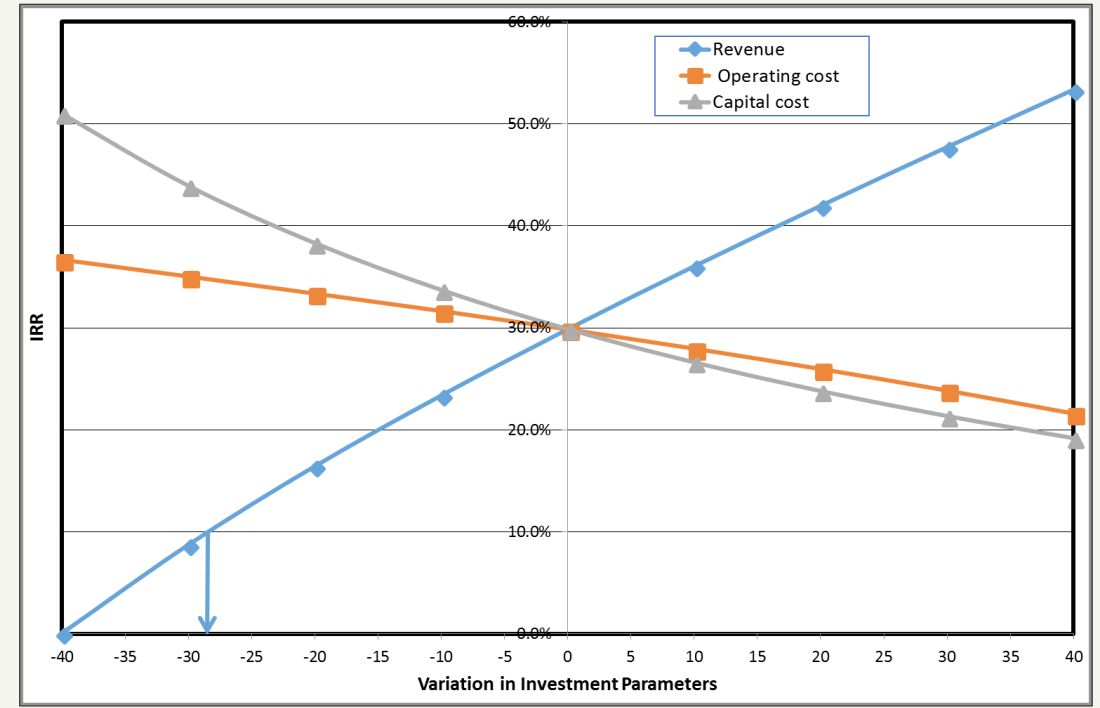

Figure 2: Variation of economic parameters with IRR.

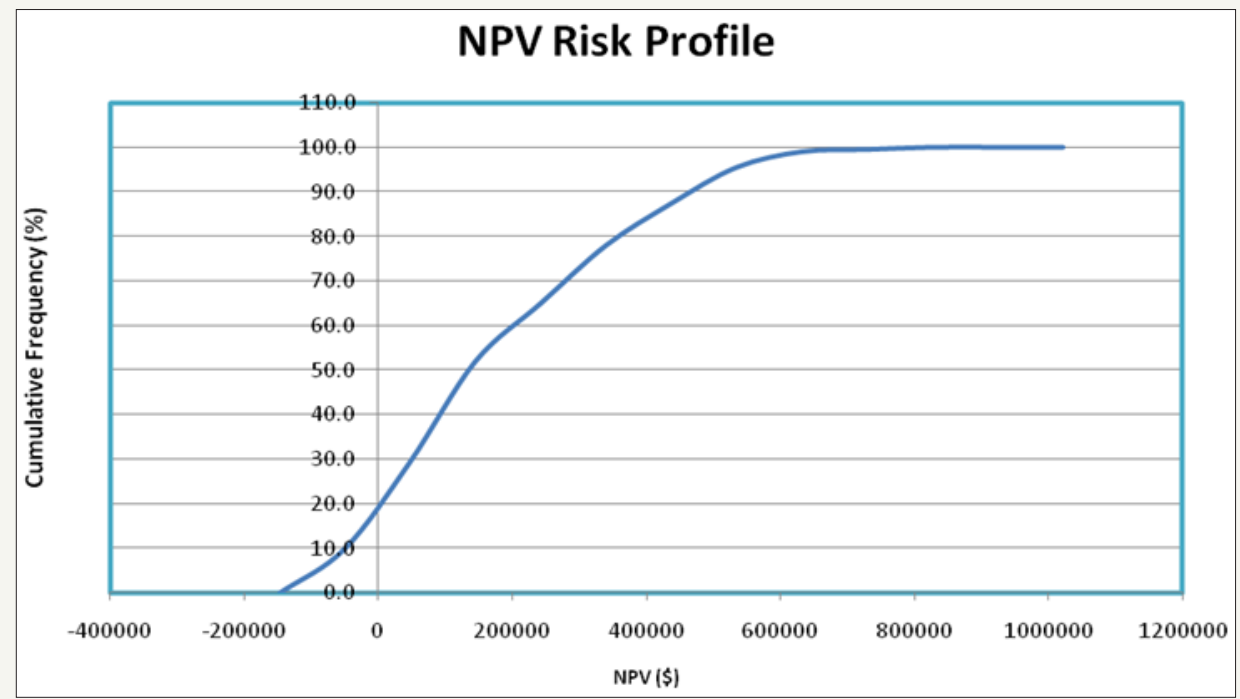

Figure 3: Risk profiles of NPV.

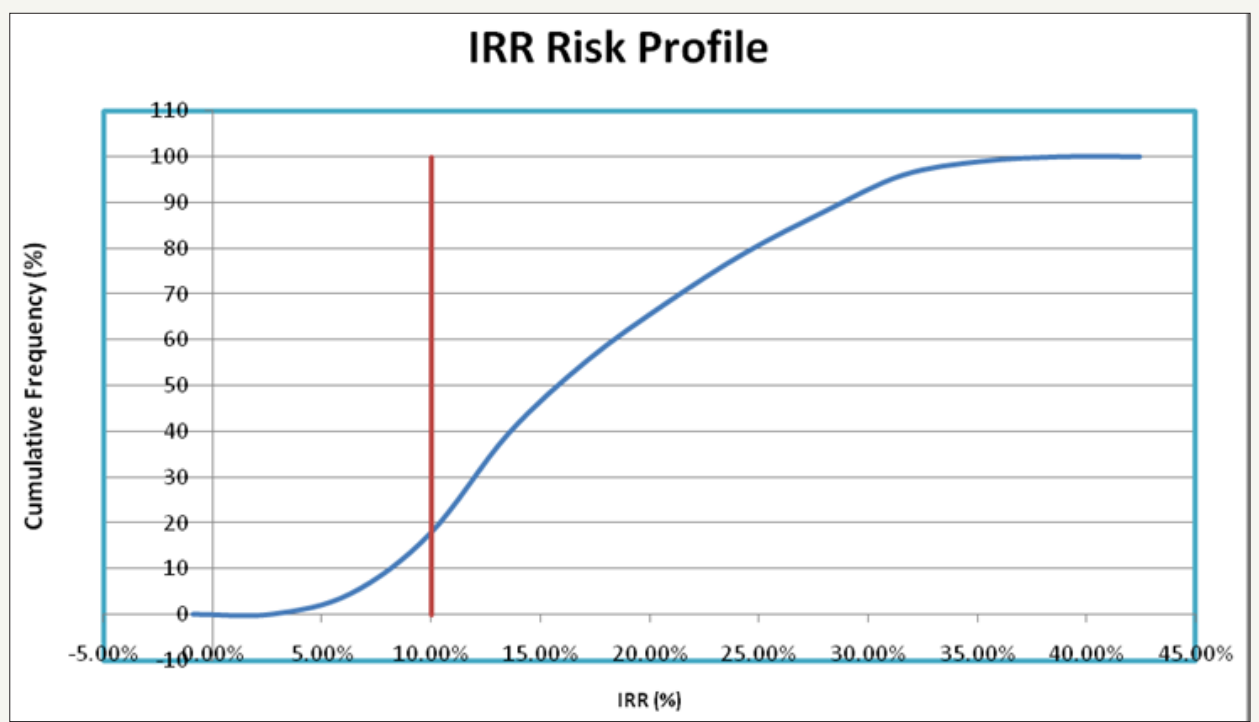

Figure 4: Risk profiles of IRR. 
Results of the sensitivity analysis are presented graphically in Figure $1 \& 2$. The project will cease to be economically viable should the revenue decrease below $28.5 \%$. The project will still remain viable after $40 \%$ increment in both the capital and operating costs.

\section{Project risk analysis using monte carlo simulation}

Figure $3 \& 4$ presents the risk profiles from the risk analysis of the Bisha VMS Project. From the risk analysis the project is associated with a risk of failure of $18 \%$.

\section{Conclusion and Recommendations}

\section{Conclusion}

The economic viability of the Bisha VMS deposit has been analysed under robust and careful technical conditions considering the Mining and Mineral Laws of Eritrea. NSR values were modelled as in most cases of poly metallic deposits and a script was developed in Surpac to calculate these values to facilitate the preparation of economic model for the evaluation of the deposit.

A total capital of US $\$ 491380000$ will be required for the project. The estimated Mine operating cost for the total life of mine is US \$947 592000 and an estimated total revenue of US \$2 615 801000 has been projected. Using a capital structure of $100 \%$ equity a cash flow analysis has been conducted which resulted in a Net Present Value of US \$344553000@10\% discount rate and an Internal Rate of Return of $29.9 \%$. The project is considered economically viable owing to the fact that the NPV is positive and the IRR is greater than the minimum rate of return.

The robustness of the projects financial performance has been tested with simple sensitivity analysis which reveals that the project is sensitive to variations in the project revenue and less sensitive to the capital and operating costs. The project will continue to be viable economically until the revenue is decreased by $28.5 \%$. Risk analysis using more rigorous Monte Carlo simulation indicated a risk of failure of $18 \%$.

\section{Recommendations}

The following recommendations have been made:

a. Extensions to the Primary massive sulphide mineralisation, including the Primary Zn Domain, should be tested with further drilling. This may have the effect of increasing the mineable reserve and extend the project life.

b. The financial structure can be analysed critically considering other sources of financing such as loan to further improve the projects NPV.

\section{Acknowledgement}

The authors are grateful to the management of Bisha Mining Share Company, Eritrea for giving them the opportunity to undertake this study at the mine. We also appreciate the support and advice of the Mine Manager Kevin Rogan, and Jay Melnyk, Mine Planning Consultant, AMEC.

\section{References}

1. Gentry DW, O'Neil TJ (1984) Mine investment analysis, society of mining engineers, American Institute of Mining, metallurgical and petroleum engineers, New York, USA, p. 510.

2. Torries TF (1998) Evaluation of mineral projects: applications and misconceptions, society for mining and metallurgy, an exploration, Littleton, USA, p. 151.

3. De La Vergne JN (2003) Hard rock miner's handbook. (3 ${ }^{\text {rd }}$ edn), M Cintosh Engineering, Ontario, Canada, p. 314.

4. Tschabrun D (2005) Economic evaluation of mining projects. Pin Cock Perspectives 71: 4.

5. Eshun PA, Mireku GD (2011) Economic evaluation of mineral projects: a socio-environmental and economic (SEE) model for gold projects, Lambert Academic Publishing (LAP), Dutchland, Germany, p. 259.

6. Rozman LI (1998) Measuring and managing the risk in resources and reserves, ore reserves and finance seminar, the australasian institute of mining and metallurgy, Melbourne, Australia, pp. 43-56.

7. Seymour C (1998) Risk analysis in open pit mine planning proceedings of the ausimm annual conference, The Australasian Institute of Mining and Metallurgy, Melbourne, Australia 98: 129-134.

8. Sayers PB, Meadowcroft I, Hall J (2002) Towards risk-based flood hazard management in the UK. Proceedings of the Institution of Civil Engineers 150(1): 36-42.

9. Eshun PA, Baafi N (2018) Optimal open pit design and life of mine scheduling of the Bisha volcanogenic massive sulphide deposit. Ghana Journal of Technology 2(2): 70-78.

10. Thomas DG (2011) NI 43-101 technical report. Nevsun Resources Limited, Canada, pp. 34-84.

11. Sorentino C, Barnett DW (1994) Financial risk and probability analysis in mineral valuation, in proceedings mineral valuation methodology 1994 valmin '94. The Australasian Institute Of Mining and Metallurgy, Melbourne, Australia, pp. 81-101.

12. Barish NN, Kaplan S (1978) Economic analysis for engineering and managerial decision making, Mc Graw Hill, New York, USA, 454(406): 20.

13. Sturgal JR, Harrison JF (1987) Using a special computer language for simulating coal mines, The Coal Mining Journal 18: 21-28.

14. Shamblin JE, Stevens GT (1974) Operations research a fundamental approach, McGraw-Hill Book Co, New York, p. 151. 

(c) (i) Creative Commons Attribution 4.0

For possible submissions Click Here

Submit Article
AMMS $1=$

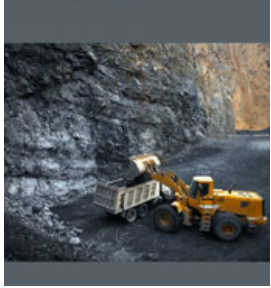

\section{Aspects in Mining \& Mineral Science}

\section{Benefits of Publishing with us}

- High-level peer review and editorial services

- Freely accessible online immediately upon publication

- Authors retain the copyright to their work

- Licensing it under a Creative Commons license

- Visibility through different online platforms 